disease, ubiquitous in the tropics, are so closely associated with malnutrition that, in practice, it is difficult to disentangle the ill-effects each produces. Cultural and social factors are of vital importance in causation. The primary preventive measures are economic development, increasing the supply and availability of the necessary foods, public health measures to combat infections and popular education in nutrition. Economic development lies beyond the scope of the symposium and so does the general development of agriculture, animal husbandry and fisheries through the use of improved techniques. But we are closely concerned with ways and means of influencing and orientating food production so that nutritional requirements are met, and of ensuring that the most effective use is made of the foods that are produced. Food science-which I take to mean the study of foods and food values in relation to requirements-and food technology, wisely applied, are both needed for these purposes.

The following papers describe some of the contributions which food science has made and is making, and give an indication of what it may accomplish in the future; and they also demonstrate the application of food technology in enabling the best use to be made of available food supplies, in utilizing new sources of food, in conserving the nutritive value of foods and increasing their palatability and acceptability, and so on. That is what the symposium is about. Another important theme running through the papers is the need for popular education, which must accompany all other measures to improve diets. Dr Wilson's paper (Wilson, r96I) on the social aspects of nutritional change will have a close bearing on this subject.

Some years ago, after having spent some ro years in directing nutrition research in India, I remarked that India needed not more nutrition research but food. I said this in a mood of discouragement and take it back, as far as nutrition research is concerned. Our symposium will, I think, amply demonstrate that nutrition research or food science must play an increasing role in the campaign against malnutrition.

\title{
REFERENCES
}

Rao, K. S., Swaminathan, M. C., Swarup, S. \& Patwardhan, V. N. (1959). Bull. World Hlth Org. 20, 603.

Thomson, F. A. (1960). Bull. Inst. med. Res. F.M.S. no. 10.

Wilson, A. T. M. (1961). Proc. Nutr. Soc. 20, 133.

\section{Problems and some solutions: introduction}

By B. S. PlatT, Human Nutrition Research Unit, National Institute for Medical Research, The Ridgeway, Mill Hill, London, N.W.7

One of the most pressing needs at the present time in the campaign against malnutrition (including undernutrition) is for trained specialist nutrition workers sufficiently experienced and qualified to direct nutrition services and to provide leadership for effective action programmes. There has been a tendency to regard nutrition as being primarily a medical subject and though, at the outset of any 
campaign, the recognition of malnutrition and of other diseases that contribute to the exacerbation of malnutrition is of paramount importance and the evaluation of any methods undertaken is ultimately largely a medical matter, the eradication of malnutrition and the maintenance of health in so far as this can be achieved by good nutrition is a matter of ensuring adequate food supplies and the proper use of such supplies, i.e. good husbandry and good housewifery. It is characteristic of applied nutrition activities that they involve a number of disciplines, not only those concerned with health and with crop and animal husbandry, but also those to do with food storage, processing and preparation as well as with education and training. There is a necessary and commendable increase in the recognition of the contribution that nutritionally sound practices in food technology can make to the eradication of malnutrition and to the maintenance of good nutrition. Gross losses of food notably during storage can be prevented; and, in more subtle ways, nutrients can be conserved in the milling of grains, e.g. by parboiling, as is practised in parts of the Far East for rice and in the Middle East for wheat.

After harvest, insects, mites, rodents and fungi destroy $10 \%$ of the total world production of food grains (Pawley, Kesteven, Dion, Molenaar, Silow, Faunce, Logothetis \& Ling, 1954). It has been estimated that, of a total production (without the U.S.S.R.) of 856000000 metric tons in 1958 , the grain lost because of improper storage would have been sufficient to feed 300 millions of people for I year. Much of this loss occurs where the grain is most needed, i.e. in villages a long way from the supplies of surplus stocks and where, under primitive conditions and in hot, humid climates, losses are as high as 50\% (as in the tropical zones of Latin America).

Heating during the drying of fish and meat can cause substantial reductions in the biological value of their proteins; these reductions in biological value have been known to exceed $50 \%$, which is equivalent to a total loss of more than half the quantity of protein of very good value.

One man in four in middle Africa is said to work for pests!

A department of food science and technology strategically placed in a centre of higher education in a developing country could be an education and training ground as well as a meeting place for students who later may become teachers and workers in a variety of disciplines and whose co-operation in the future in the campaigns against malnutrition will be essential.

The next five papers should be considered not only on their intrinsic merit but they should also serve as examples of the lines along which postgraduate teaching, training and research is being developed in the Department of Human Nutrition at the London School of Hygiene and Tropical Medicine and at the Human Nutrition Research Unit of the Medical Research Council. There is a particularly urgent need for trained personnel (Platt, 1956) in developing countries to help in sizing up problems, in planning food policies having a sound nutritional basis and to help in initiating and developing action programmes designed to eradicate malnutrition and ultimately to build up nutrition services and nutrition education activities through which the health and welfare of the population can be sustained as far as it can be achieved by adequate feeding. 
The five speakers will, no doubt, some day be key personnel in food science and nutrition activities in their respective countries where the need for more and better food is often so great.

\section{REFERENCES}

Pawley, W. H., Kesteven, K. V. L., Dion, G., Molenaar, A., Silow, R. A., Faunce, A. D., Logothetis, C. \& Ling, L. (1954). World Pop. Conf. Rome, $5,452$.

Platt, B. S. (1956). Int. Congr. Diet. II. Rome, p. 243.

\section{Problems and some solutions: India}

By K. Halder, Human Nutrition Research Unit, National Institute for Medical Research, The Ridgeway, Mill Hill, London, N.W.7

Food production and population growth

The most pressing problem of India today is that of providing adequate food for the population of 400 million. India had to face this enormous challenge, just after Independence, against the background of the postwar depression and insufficient food production. The Government of India, in the first Five Year Plan, laid maximum emphasis on food production and on improving irrigation systems throughout the country by constructing river-valley projects and setting up fertilizer factories. Food production gradually increased, but the growth of population remained unchecked so that the per caput supply of food is still inadequate. The daily energy value of the food supplies increased from $1700 \mathrm{kcal} / \mathrm{head}$ in $1949-50(\mathrm{FAO}, \mathrm{r} 953)$ to $1890 \mathrm{kcal}$ in $1955^{-6}$ (FAO, I958) and the target of $2000 \mathrm{kcal}$ for 1960 (FAO, I953) has already been reached. Even now, however, the energy value of the diets falls below the estimated requirement. In the near future, with further development of agriculture, India will, no doubt, be able to provide adequate calories for the population.

In the early plans, there was little recognition of the nutritional aspects of food policy, and efforts were concentrated almost exclusively on the production of staple foods. In particular, agriculturists were apparently quite unaware of the importance of producing protective foods, or indeed of the need for strenuous efforts to increase the supply of staple foods. Hardly any of them were taught anything about human nutrition. It is, however, beginning to be realized that not only must the production of staple crops be greatly increased but also that the pattern of agriculture will have to be changed in order that in the future the people of India will have enough of the right kind of foods.

\section{Inadequacy of animal products}

India's food balance sheet (FAO, I958) shows a striking deficit of foods of animal origin. The total protein supply is inadequate and, in particular, there is insufficient 